\title{
Article \\ Consolidation and Adhesion of Pictorial Layers on a Stone Substrate. The Study Case of the Virgin with the Child from Palazzo Madama, in Turin
}

\author{
Anita Negri ${ }^{1}$, Marco Nervo ${ }^{2, *(1)}$, Stefania Di Marcello ${ }^{3}$ and Daniele Castelli ${ }^{4}$ \\ 1 Science for Conservation, Restoration, Exploitation of Cultural Heritage, University of Turin, \\ 10125 Turin, Italy; anitanegri.1990@gmail.com \\ 2 Head of Scientific Laboratories, Foundation Centre for Conservation and Restoration "La Venaria Reale", \\ 10078 Venaria Reale, Italy \\ 3 Art Conservator, Superintendence of Archaeology, Fine Arts and Landscape for the City of L'Aquila, \\ 67100 L'Aquila, Italy; stefania.dimarcello@beniculturali.it \\ 4 Department of Earth Sciences, University of Turin, 10125 Turin, Italy; daniele.castelli@unito.it \\ * Correspondence: marco.nervo@centrorestaurovenaria.it
}

Citation: Negri, A.; Nervo, M.; Di

Marcello, S.; Castelli, D.

Consolidation and Adhesion of

Pictorial Layers on a Stone Substrate. The Study Case of the Virgin with the Child from Palazzo Madama, in Turin. Coatings 2021, 11, 624. https:// doi.org/10.3390/coatings11060624

Academic Editor: Maude Jimenez

Received: 29 April 2021

Accepted: 20 May 2021

Published: 23 May 2021

Publisher's Note: MDPI stays neutral with regard to jurisdictional claims in published maps and institutional affiliations.

Copyright: (c) 2021 by the authors. Licensee MDPI, Basel, Switzerland. This article is an open access article distributed under the terms and conditions of the Creative Commons Attribution (CC BY) license (https:/ / creativecommons.org/licenses/by/ $4.0 /)$.

\begin{abstract}
The study and the restoration of a polychrome limestone statue representing the Virgin with the Child, from Palazzo Madama in Turin (NW Italy) offered interesting conservation issue related to the polychromy on stone. To preserve the pictorial layers, it was necessary to re-establish the cohesion among the different polychrome layers (original and repainted) and the adhesion between polychrome film and the stone substrate. Particular attention was paid to the choice of intervention materials, selected through a preliminary survey of the scientific literature, and then verified by laboratory tests (tape test, colorimetric test, and permeability test). The most suitable product should to be able to penetrate porosity, to consolidate the layers, to make the pictorial film adhere with the stone surface, and to avoid changes in the colour and in the permeability. The material chosen also had to ensure compatibility with the cleaning method that could only take place after the consolidation of the pictorial layers due to the problematic state of preservation. A range of products, characterised by their small particle size and low viscosity, was tested, and a micro-acrylic resin was selected and successfully applied on the polychromy of the sculpture.
\end{abstract}

Keywords: polychromy; polychrome stone statue; adhesion and cohesion products; conservation of pictorial films on stone

\section{Introduction}

A polychrome stone consists of a complex and heterogeneous system: the stone substrate and one or more pictorial layers covering the stone. The first is inorganic, porous, transpiring, and hydrophilic; the second ones are less transpiring, partially organic (dyes and several types of binder media), and partially inorganic (mineral pigments). The approach to the consolidation and the adhesion of the pictorial layers covering stone sculptures, therefore, is not uniquely defined.

The object of this study is a polychrome limestone statue representing the Virgin with the Child, from Palazzo Madama in Turin (Figure 1) [1-3]. The work of art has been the subject of a thesis work [4] University of Turin in collaboration with the Foundation Centro Conservazione e Restauro "La Venaria Reale", during the academic year 2017-2018.

Based on comparisons [5-7], the bodies of Mary and Jesus can be attributed to the French style of the 14th century. The head of the Virgin is stylistically similar to some French pieces of the 15th century [8]. The head of the Child is a plaster cast hypothetically made between the 19th and the 20th century, most likely to replace the original missing piece, and it has not been painted. The bodies of the Virgin and the Child are carved in a fine-grained, carbonate sedimentary rock of uncertain provenance, that can be defined as biopelsparite as 
shown by analysing some samples of the stone under an optical microscope in transmitted polarised light. Mary's head is composed of a carbonate lithotype, a different, more porous and finer-grained limestone. A sample of the the lithotype was observed under an optical microscope and a scanning electron microscope and analysed with an EDX probe. The statue is covered by numerous fragments of pictorial layers, composed of mineral pigments, dyes, and metallic foils characterised by SEM-EDX and FT-IR analyses. The identified inorganic pigments are white lead, gypsum, lead-tin yellow, yellow, brown and red ochre, minium, cinnabar, copper resinate, a different type of a copper-based pigment (verdigris or malachite or chrysocolla), azurite. The analyses also revealed the presence of indigo dye, a red dye and gold and silver foils. For some of the pigments an oil was identified as the binder medium, while in other cases it was no possible to identify the binder by FT-IR analysis. In these cases, FT-IR analyses only revealed the presence of oxalates, together with the pigments. This data led to the hypothesis that the painting technique consisted in a lean tempera (using gums, egg white, calcium dairy or animal glue as binder).

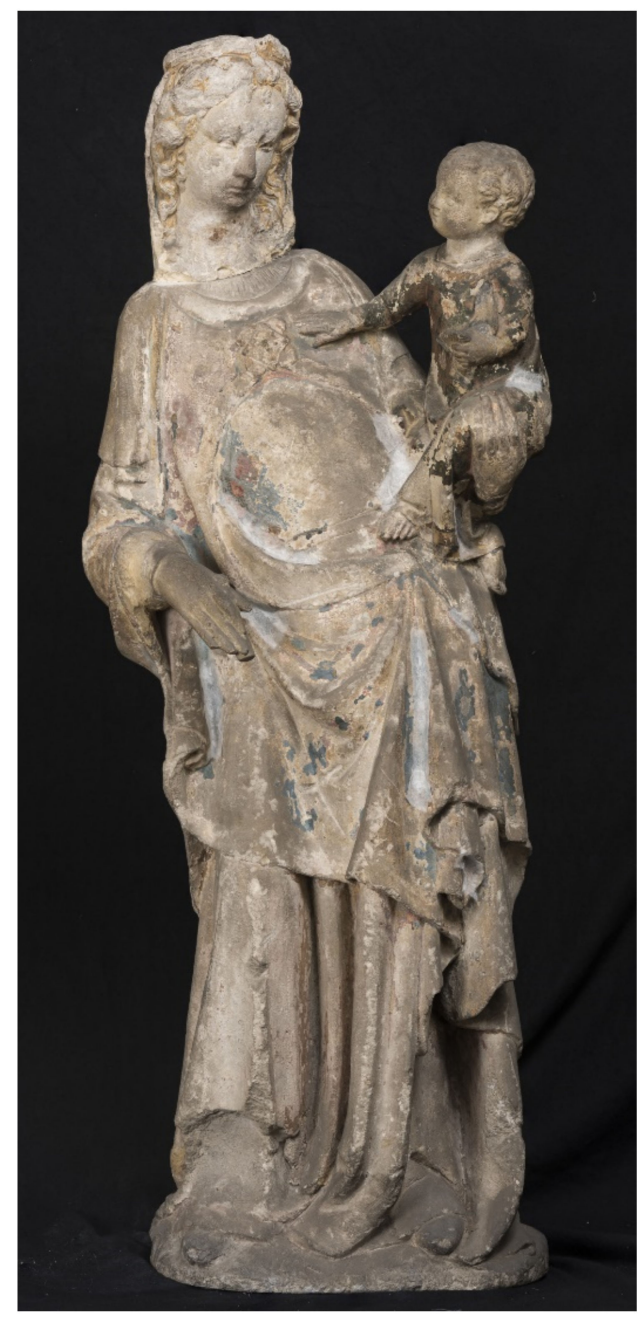

(a)

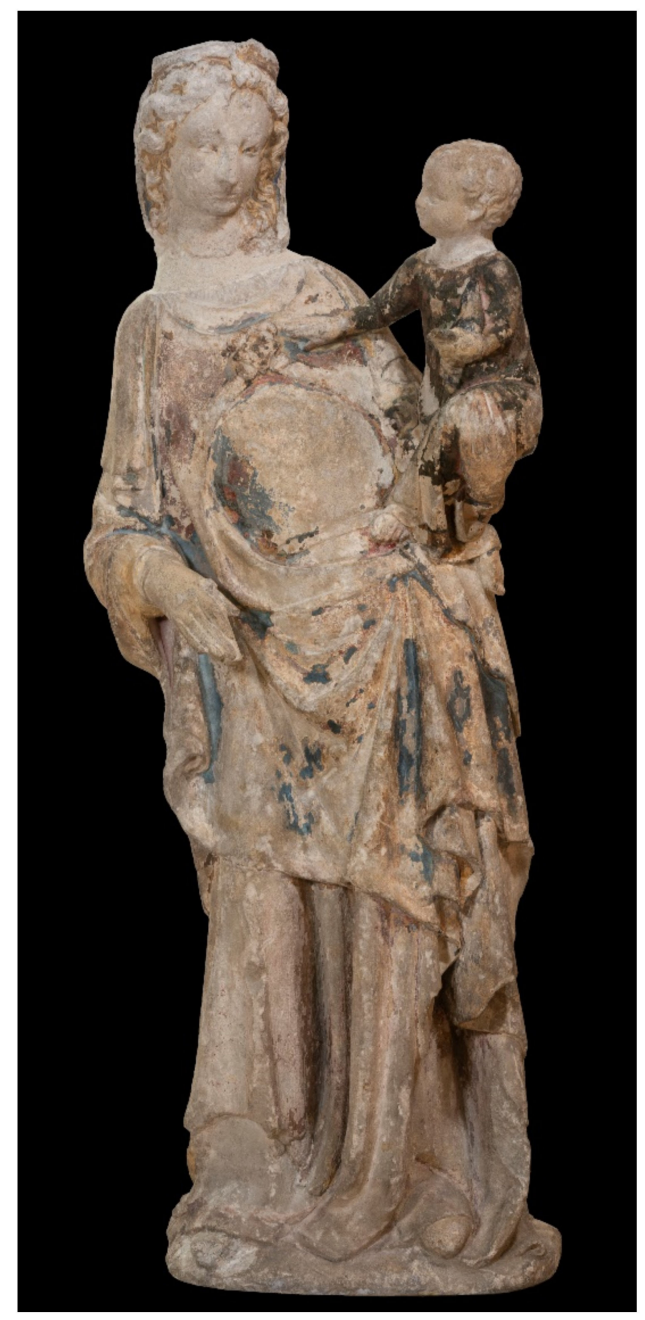

(b)

Figure 1. The Virgin with the Child from Palazzo Madama in Turin, before (a) and after (b) the restoration.

Some constituent elements of the pictorial layers are altered or degraded. The presence of oxalates is perhaps due to the hydrolysis of the proteins which compose the binder of some pictorial layers and the consequent interaction of the resulting free fatty acids with metal ions from the pigments, the substrate or the environment $[9,10]$. The siccative oil is subjected to oxidation, cross-linking and depolymerisation, resulting in the formation of by-products $[9,11,12]$ and loss of cohesion and adhesion. Among the by- 
products there are groups of free fatty acids, which bind to metal cations coming from the atmosphere or pigments or even from the stone substrate, producing metal soaps [12-14], detected by SEM-EDS analysis. They are subjected to phase changes, resulting in migrations and re-crystallisations within the polychrome layers or in one of the interfaces, forming translucent masses $[12,15-17]$ and causing the formation of bumps on the surface. The analyses revealed the presence of sulphates, probably resulting from the transformation of carbonates (from the stone material, azurite and malachite) by the atmospheric particulate matter and humidity [18]. While the thermo-hygrometric parameters vary, these sulphates are subjected to crystallisation-solubilisation cycles, causing mechanical tensions, which lead to the embrittlement of the pictorial films. Cinnabar is altered in some points, probably due to the photo-oxidation or the interaction with the white lead or with the carbonate of the stone substrate $[19,20]$. Malachite also is altered, perhaps due to the interaction with soluble salts [20,21]. Finally, the presence of $\mathrm{AgCl}$ in silver foils is probably due to chlorides from the atmosphere [22]. The severe state of decohesion and loss of adhesion, required a consolidation and adhesion intervention, since the control of the thermohygrometric parameters was not enough to conserve them.

\section{Materials and Methods}

To select the most suitable restoration material for this case study, organic (synthetic and natural) and inorganic products were selected on the basis of the evaluation of their characteristics through a bibliographic research and then their testing on mock-ups as representative as possible of the stone-pictorial layers system found for the Virgin with the Child. The tested products are listed in Table 1.

Table 1. Tested products.

\begin{tabular}{|c|c|c|}
\hline Synthetic Organic Resins & Natural Organic Resins & Inorganic Products \\
\hline $\begin{array}{l}25 \% \text { and } 50 \% \text { Acril } \mathrm{ME}^{\circledR} \text { (by C.T.S.) [23] in } \\
\text { demineralised water and } 10 \% \text { ethanol }\end{array}$ & $\begin{array}{c}1 \% \text { and } 3 \% \text { Jun Funori (by Lascaux } \\
\text { Colours \& Restauro) in demineralised } \\
\text { water [24-29] }\end{array}$ & $\begin{array}{l}2 \% \text { and } 5 \% \text { Ammonium oxalate (by } \\
\text { Sinopia) in demineralised water }[30,31]\end{array}$ \\
\hline 100\% Acrylmat (by AN.T.A.RES) [23] & $\begin{array}{l}\text { rabbit skin glue (by C.T.S.) in a ratio of } \\
1: 14 \text { in water }[24,25]\end{array}$ & $\begin{array}{l}\text { 100\% Nanolime CaLoSiL }{ }^{\circledR} \text { E25 (by } \\
\text { IBZ-Salzchemie GmbH \& Co. KG) [32] }\end{array}$ \\
\hline $\begin{array}{l}8 \% \text { and } 16 \% \text { Dispersion }{ }^{\circledR} \mathrm{K} 52 \text { (by Kremer } \\
\text { Pigmente) in demineralised water }[33-35]\end{array}$ & $\begin{array}{c}\text { sturgeon glue (by AN.T.A.RES) in a ratio } \\
\text { of 1:20 in water [25] }\end{array}$ & - \\
\hline $\begin{array}{l}33 \% \text { and } 50 \% \text { Micral-Primal WS- } 24^{\circledR} \text { (by } \\
\text { Kremer Pigmente) in demineralised water }\end{array}$ & - & - \\
\hline $\begin{array}{l}5 \% \text { and } 10 \% \text { Microacril }^{\circledR} \text { CV40 (by Chem } \\
\text { Spec) in demineralised water [36] }\end{array}$ & - & - \\
\hline $\begin{array}{c}3 \% \text { and } 10 \% \text { Aquazol }^{\circledR} 200 \text { (by Polymer } \\
\text { Chemistry Innovations) in demineralised } \\
\text { water and } 10 \% \text { ethanol }[25,37-40]\end{array}$ & - & - \\
\hline $100 \%$ Fluoline ${ }^{\circledR}$ HY (by C.T.S.) [41] & - & - \\
\hline $\begin{array}{c}10 \% \text { and } 20 \% \text { Regalrez }{ }^{\circledR} 1126 \text { (by C.T.S.) in } \\
\text { ligroin }[24,42]\end{array}$ & - & - \\
\hline $\begin{array}{c}2 \% \text { and } 4 \% \text { Tylose }{ }^{\circledR} \text { MH 300p (by C.T.S.) in } \\
\text { demineralised water [37] }\end{array}$ & - & - \\
\hline
\end{tabular}

Blocks $(5 \mathrm{~cm} \times 5 \mathrm{~cm} \times 1 \mathrm{~cm})$ were prepared with lime putty and limestone dust in a ratio of 1:3. Vinci limestone powder was selected as an aggregate: it is entirely composed of calcium carbonate and was sieved to select aggregates with $\leq 200-300 \mu \mathrm{m}^{3}$ dimensions (Figure 2). A plaster rasp was used to imitate the tooth chisel processing, obtaining a material which was similar to the constituting stone of the bodies of the Virgin and the Child, from a chemical and morphological point of view, as verified by an optical 
microscope. Since the polychrome stratigraphy of the work of art is very complex and extremely heter-ogeneous, a simplification was implemented to realise the mock-ups, even though in our opinion their representativeness was not compromised. Therefore, rather than reproducing all the layers of each area of the sculpture, only two pictorial layers were prepared. One was composed of red ochre, white lead and siccative oil (linseed oil), the other consisted of yellow ochre, white lead, and animal glue. The two pictorial layers were spread by brush on sheets of Melinex ${ }^{\circledR}$; once dried, they were peeled off and subjected to artificial aging. During the present case study, the artificial aging in the stove lasted twenty-two days: for eleven days the temperature was kept at $60{ }^{\circ} \mathrm{C}$ and then at $110{ }^{\circ} \mathrm{C}$ for another eleven days. Following this treatment, it was possible to observe a notable stiffening of the pictorial layers and a slight variation in the colours.

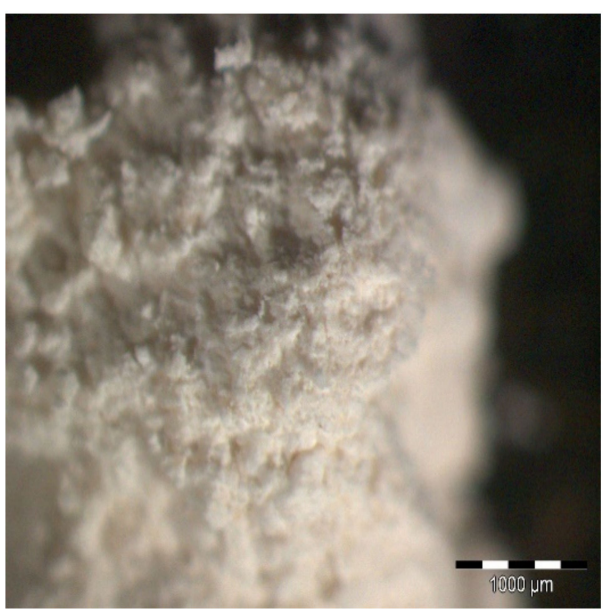

(a)

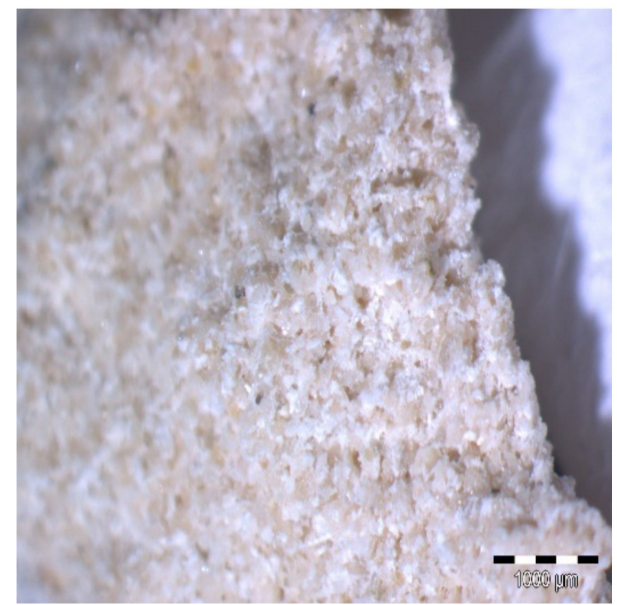

(b)

Figure 2. (a) One of the mortar samples seen under the optical microscope, with $25 \times$ magnification. (b) Sample of lithotype from the base of the bodies of the Virgin and the Child, seen under the optical microscope, with $25 \times$ magnification.

The adhesive power, which is considered to be the most important requirement in this case study, was evaluated with tape tests.

Each product tested was applied on a mock-up composed by the block representing the lithotype, covered by an oil painting layer and, on top, one tempera layer, both laid in fragments. The tested products were applied by syringe, allowing them to penetrate between the layers (Figure 3). The effectiveness of the organic resins was evaluated three to four days after the first application; in the case of a visible inefficacy, the product was applied a second time. Inorganic consolidants were applied four to six times. Regarding the case of nanolime, the tape test was performed thirty days after its application. Regarding each product to be tested, three pieces of Scotch ${ }^{\circledR} 3 \mathrm{M}$ were applied in three different points on the surface of each sample and then de-attached. After this, the average weight difference between the piece of tape after and before the application was calculated, using an Acculab ALC-210.4 analytical balance (Acculab, New York, NY, USA), with readability $0.1 \mathrm{mg}$. The lower the resulting value, the greater the adhesive strength of the product. The mock-ups were photographed before and after the test (Table A1, Appendix A), to see and record which layers adhered and, consequently, to evaluate the penetration capacity of the products among the different interfaces. 


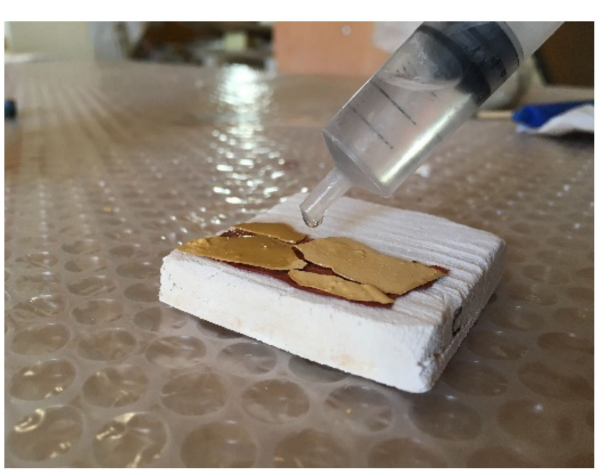

(a)

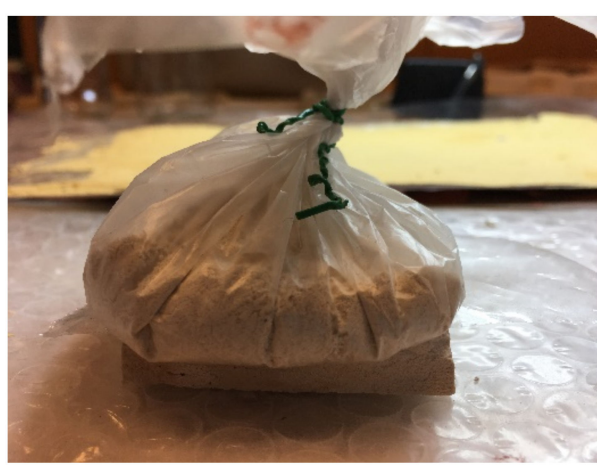

(b)

Figure 3. (a) Application of a resin upon a sample. (b) After the application of the product, on each specimen a weight was placed, with the interposition of a Melinex ${ }^{\circledR}$ sheet, to increase the adhesion between the layers.

The products resulting with a satisfactory adhesion strength were then subjected to the colorimetric test. The Italian recommendation NorMaL 43/93 defines the colorimetric coordinates collection on opaque surfaces of stone materials which are subjected to alterations and conservative treatments. According to NorMaL 43/93 it is possible to perform a quantitative measurement of the colour variation by detecting the colorimetric coordinates before and after the application of the product. During the present case study, a KonicaMinolta CM-700d colorimeter (Tokyo Metropolis, Japan) was used, which was equipped with a pulsed xenon lamp and an integrating sphere for diffused illumination of the sample (geometry d/8, illuminant D65, measurement conditions SCI + SCE, measurement step $10 \mathrm{~nm}$, spectral range 400-700 nm). The acquisitions were performed on an oil painting film (prepared as above described). Each product was applied with a brush in a single coat. After drying, three colorimetric measurements of three distinct points were conducted for each sample.

Finally, the most suitable product must not form a water vapour impermeable film. To perform a water vapour permeability test, reference was made to the European standard EN ISO 12572 (June 2001 edition), which describes a method for determining the hygroscopic permeance of building products and materials in an environment characterised by constant temperature and relative humidity. The test was performed on samples consisting of a waterproof box containing water, with an opening, entirely covered by a mortar block (prepared as already described). Each product to be tested was applied in two layers by brush on the surface of three blocks, trying to obtain a uniform and similar application for all mock-ups. Due to the different partial pressure of the water vapour between the box and the external environment, the vapour passed through the blocks of stone material. Via periodically weighing the system, it was possible to detect the flow of water vapour that passed through the porosity of the material, determining its hygroscopic permeance. During this case study we did not want to acquire absolute measurements, but relative data, thus, to compare the difference in permeability of a porous material following a treatment with resins.

\section{Results}

The adhesive strength, which is considered to be the most important requirement in this case study, has been evaluated with tape test. Then, the products with a satisfying adhesive strength have been subjected to colorimetric tests, to evaluate the possible change in colour, and to permeability tests, to evaluate the variation of this parameter in the stone substrate after consolidation. 


\subsection{Adhesion Test}

Seen in Table 2 and in Table A1 in Appendix A, with $10 \%$ and $20 \%$ Regalrez $^{\circledR}$, rabbit glue, $\mathrm{CaLoSil}{ }^{\circledR}$, and $5 \%$ ammonium oxalate, no adhesion was obtained, so performing the tape tests was deemed unproductive. The $3 \%$ and $10 \%$ Aquazol $^{\circledR} 200,5 \%$ Microacril $^{\circledR}$ CV40, sturgeon glue $1: 20$, and $2 \%$ ammonium oxalate did not get a satisfactory adhesion between the layers. A better, but not sufficient, result was achieved with Micral-Primal ${ }^{\circledR}$ WS-24 at $33 \%$ and $50 \%$, Acryl ME ${ }^{\circledR}$ at $25 \%$ and pure Fluoline ${ }^{\circledR}$ HY (applied twice), and with Microacril ${ }^{\circledR}$ CV40 at $10 \%$ (applied once). The $50 \%$ Acryl $\mathrm{ME}^{\circledR}$, pure AcrilMat ${ }^{\circledR}, 8 \%$ and $16 \%$ Dispersion ${ }^{\circledR}$ K52, 3\% Funori, $2 \%$ and $4 \%$ Tylose ${ }^{\circledR}$ MH300 showed a good adhesive strength. Nevertheless, it should be noted that the Acryl ME ${ }^{\circledR}$ and pure AcrilMat ${ }^{\circledR}$ were effective only after two applications. The first application the products likely penetrated within the porosity too in depth. Despite the effectiveness of the second application, it was decided to discard these two resins for the application on the sculpture, because their excessive penetrability makes the cohesion/adhesion operation difficult to control. The $50 \%$ Acril ME ${ }^{\circledR}, 5 \%$ Microacril ${ }^{\circledR} \mathrm{CV} 40$, and $2 \%$ ammonium oxalate achieved good adhesion between the two pictorial layers, but not between these latter and the stone substrate.

Table 2. Tape test. Difference was calculated as weight after the test and before the test.

\begin{tabular}{|c|c|c|c|}
\hline Sample Name & $\begin{array}{c}\text { Number of Applications of } \\
\text { the Consolidant }\end{array}$ & Difference of Weight (mg) & $\begin{array}{l}\text { Average Weight of the Scotch } \\
\text { Tape after Tape Test (mg)* }\end{array}$ \\
\hline & & 243 & \\
\hline \multirow[t]{3}{*}{$25 \%$ Acryl ${ }^{\circledR} \mathrm{ME}$} & 2 & 47 & $116 \pm 98$ \\
\hline & & 57 & \\
\hline & & 33 & \\
\hline \multirow[t]{3}{*}{$50 \%$ Acryl $^{\circledR} \mathrm{ME}$} & 2 & 56 & $46 \pm 11$ \\
\hline & & 49 & \\
\hline & & 0 & \\
\hline \multirow[t]{3}{*}{ Acrylmat $^{\circledR}$} & 2 & 0 & $0 \pm 0$ \\
\hline & & 0 & \\
\hline & & 796 & \\
\hline \multirow[t]{3}{*}{$3 \%$ Aquazol ${ }^{\circledR} 200$} & 2 & - & no adhesion \\
\hline & & - & \\
\hline & & 344 & \\
\hline \multirow[t]{3}{*}{$10 \%$ Aquazol $^{\circledR} 200$} & 2 & 552 & no adhesion \\
\hline & & - & \\
\hline & & 0 & \\
\hline \multirow[t]{3}{*}{$16 \%$ Dispersion ${ }^{\circledR} \mathrm{K} 52$} & 1 & 0 & $0 \pm 0$ \\
\hline & & 0 & \\
\hline & & 0 & \\
\hline \multirow[t]{3}{*}{$8 \%$ Dispersion ${ }^{\circledR} \mathrm{K} 52$} & 1 & 0 & $0 \pm 0$ \\
\hline & & 0 & \\
\hline & & 132 & \\
\hline \multirow[t]{3}{*}{ Fluoline ${ }^{\circledR} \mathrm{HY}$} & 2 & 177 & $107 \pm 82$ \\
\hline & & 12 & \\
\hline & & 3 & \\
\hline \multirow[t]{3}{*}{$33 \%$ Micral-Primal ${ }^{\circledR}$ WS-24 } & 1 & 4 & $2 \pm 1$ \\
\hline & & 0 & \\
\hline & & 4 & \\
\hline \multirow[t]{3}{*}{$50 \%$ Micral-Primal ${ }^{\circledR}$ WS-24 } & 1 & 0 & $1 \pm 1$ \\
\hline & & 0 & \\
\hline & & 4 & \\
\hline \multirow[t]{3}{*}{ 1\% Jun Funori } & 2 & 1 & $5 \pm 5$ \\
\hline & & 11 & \\
\hline & & 0 & \\
\hline \multirow{2}{*}{$3 \%$ Jun Funori } & 2 & 1 & $0 \pm 0$ \\
\hline & & 0 & \\
\hline
\end{tabular}


Table 2. Cont.

\begin{tabular}{|c|c|c|c|}
\hline Sample Name & $\begin{array}{c}\text { Number of Applications of } \\
\text { the Consolidant }\end{array}$ & Difference of Weight (mg) & $\begin{array}{l}\text { Average Weight of the Scotch } \\
\text { Tape after Tape Test }(\mathrm{mg}) *\end{array}$ \\
\hline & & - & \\
\hline \multirow[t]{2}{*}{$10 \%$ Regalrez ${ }^{\circledR} 1126$} & 1 & $\begin{array}{l}- \\
-\end{array}$ & no adhesion \\
\hline & & - & \\
\hline \multirow[t]{3}{*}{ 20\% Regalrez 1126} & 1 & - & no adhesion \\
\hline & & - & \\
\hline & & 762 & \\
\hline \multirow{3}{*}{$5 \%$ Microacril $^{\circledR}$ CV40 } & 1 & - & no adhesion \\
\hline & & - & \\
\hline & & 0 & \\
\hline \multirow[t]{3}{*}{$10 \%$ Microacril $^{\circledR}$ CV40 } & 1 & 0 & $112 \pm 168$ \\
\hline & & 337 & \\
\hline & & 1 & \\
\hline \multirow[t]{3}{*}{ 2\% Tylose ${ }^{\circledR}$ MH 300p } & 1 & 0 & $0 \pm 0$ \\
\hline & & 0 & \\
\hline & & 0 & \\
\hline \multirow[t]{3}{*}{ 4\% Tylose ${ }^{\circledR}$ MH 300p } & 1 & 0 & $0 \pm 0$ \\
\hline & & 0 & \\
\hline & & 0 & \\
\hline \multirow[t]{3}{*}{$2 \%$ Ammonium Oxalate } & 1 & 846 & no adhesion \\
\hline & & - & \\
\hline & & - & \\
\hline \multirow[t]{3}{*}{$5 \%$ Ammonium Oxalate } & 1 & - & no adhesion \\
\hline & & - & \\
\hline & & - & \\
\hline \multirow[t]{3}{*}{ Rabbit glue Lapin } & 4 & - & no adhesion \\
\hline & & - & \\
\hline & & 748 & \\
\hline \multirow[t]{3}{*}{ Sturgeon glue } & 4 & - & no adhesion \\
\hline & & - & \\
\hline & & - & \\
\hline \multirow[t]{2}{*}{$\mathrm{CaLoSil}^{\circledR}$} & 6 & - & no adhesion \\
\hline & & - & \\
\hline
\end{tabular}

* The mean absolute error was calculated as semi-difference between the higher and the lower value, considering the limited number of measurements. This method allows not to underestimate the error.

The adhesives that showed satisfactory efficacy on the samples-2\% Tylose ${ }^{\circledR}$ MH300p, $3 \%$ Jun Funori and $8 \%$ and $16 \%$ Dispersion ${ }^{\circledR}$ K52-therefore, were selected and subjected to the following tests. The $4 \%$ Tylose MH300p was excluded, despite its good adhesive strength, as its density makes it difficult to distribute and it causes colour saturation evident to the naked eye.

\subsection{Colorimetric Test}

Seen in Tables 3-6, among the tested products, $16 \%$ Dispersion ${ }^{\circledR} \mathrm{K} 52$ caused a greater variation of the $b^{*}$ coordinate: this implies a slight yellowing of the surface, although it is not perceptible to the naked eye. The $\Delta E_{00}$ of $8 \%$ Dispersion ${ }^{\circledR} \mathrm{K} 52$ and of $3 \%$ Jun Funori slightly exceeded the value 1 , so the chromatic variation was negligible.

Table 3. Colorimetric test: Average $\Delta E_{00}$.

\begin{tabular}{cc}
\hline Resin & Average $\Delta \boldsymbol{E}_{\mathbf{0 0}}$ \\
\hline $16 \%$ Dispersion ${ }^{\circledR} \mathrm{K} 52$ & $0.99 \pm 0.32$ \\
8\% Dispersion ${ }^{\circledR} \mathrm{K} 52$ & $1.90 \pm 0.42$ \\
3\% Jun Funori & $1.13 \pm 0.24$ \\
2\% Tylose ${ }^{\circledR}$ MH300 & $0.86 \pm 0.67$ \\
\hline
\end{tabular}


Table 4. Colorimetric test: average $\Delta L^{*}(\mathrm{D} 65)$.

\begin{tabular}{cc}
\hline Resin & Average $\Delta L^{*}$ (D65) \\
\hline 16\% Dispersion ${ }^{\circledR} \mathrm{K} 52$ & $0.45 \pm 0.45$ \\
8\% Dispersion ${ }^{\circledR} \mathrm{K} 52$ & $0.34 \pm 0.55$ \\
3\% Jun Funori & $0.36 \pm 0.20$ \\
2\% Tylose ${ }^{\circledR}$ MH300 & $0.84 \pm 0.75$ \\
\hline
\end{tabular}

Table 5. Colorimetric test: average $\Delta a^{*}(\mathrm{D} 65)$.

\begin{tabular}{cc}
\hline Resin & Average $\boldsymbol{\Delta} \boldsymbol{a}^{*}$ (D65) \\
\hline 16\% Dispersion ${ }^{\circledR} \mathrm{K} 52$ & $0.45 \pm 0.38$ \\
8\% Dispersion ${ }^{\circledR} \mathrm{K} 52$ & $0.01 \pm 0.20$ \\
3\% Jun Funori & $0.18 \pm 0.26$ \\
2\% Tylose ${ }^{\circledR}$ MH300 & $0.57 \pm 0.17$ \\
\hline
\end{tabular}

Table 6. Colorimetric test: average $\Delta b^{*}(\mathrm{D} 65)$.

\begin{tabular}{cc}
\hline Resin & Average $\boldsymbol{\Delta} \boldsymbol{b}^{*}$ (D65) \\
\hline 16\% Dispersion ${ }^{\circledR} \mathrm{K} 52$ & $0.62 \pm 1.13$ \\
8\% Dispersion ${ }^{\circledR} \mathrm{K} 52$ & $0.46 \pm 0.18$ \\
3\% Jun Funori & $0.02 \pm 0.38$ \\
2\% Tylose ${ }^{\circledR}$ MH300 & $0.18 \pm 0.22$ \\
\hline
\end{tabular}

The products that caused a minor colour variation are 2\% Tylose MH300p and 8\% Dispersion ${ }^{\circledR} \mathrm{K} 52$.

\subsection{Permeability Test}

The purpose of this test is to compare the permeability of a porous material following the treatment with an intervention product. Regarding the case of a polychrome stone sculpture, the artistic technique itself leads to a reduction in permeability, since the pictorial layers tend to be less porous than the stone substrate. It is appropriate to not worsen this condition, applying where necessary a product that does not further occlude the porosity, leaving the actual level of permeability as much unaltered as possible.

As can be seen in Table 7, even though the number of samples is limited and the standard deviation is high, the test has an indicative value. It is possible to note that there were no significant differences in behaviour of the products tested, and each of them reduced permeability by approximately $20 \%$.

Table 7. Permeability test.

\begin{tabular}{cc}
\hline Resin & Total Weight Average of Evaporated Water Vapour (mg) \\
\hline No resin & $985 \pm 42$ \\
16\% Dispersion ${ }^{\circledR}$ K52 & $781 \pm 63$ \\
8\% Dispersion ${ }^{\circledR}$ K52 & $746 \pm 58$ \\
3\% Jun Funori & $764 \pm 38$ \\
\hline
\end{tabular}

\section{Discussion}

The ideal product must achieve the cohesion of the pictorial films and the adhesion between them and the stone substrate. It must not change the gloss nor colour of the pictorial surface, it must guarantee the durability over time of both physical features and colour, avoiding by-products that would be a direct or indirect cause of alteration in the future. It must allow the retractability of the intervention. Reversibility is not considered a priority since, in the future the possibility that it will be considered necessary to remove 
one or more pictorial layers is remote and this operation would be possible mechanically, as demonstrated by tests on mock-ups. Therefore, we also tested inorganic consolidants, which have excellent stability over time. The ideal product must be compatible with the chosen surface cleaning methods. During our case study, different water cleaning processes were selected, after tests were performed to remove consistent deposits from the different materials of which the sculpture is made. The consolidation study started when it was not possible to select the suitable cleaning method yet; for this reason, water-sensitive products were initially included.

The critical conservative state of the pictorial layers required us to achieve the consolidation and the adhesion of polychromy simultaneously or, in some cases, even before the surface cleaning. A pre-consolidation would have fixed the substantial coherent deposits, while a preliminary cleaning would have compromised the conservation of the pictorial films. A Long Q-Switch (LQS) laser (El.En. S.p.a., Florence, Italy) was tested on some detached fragments, as this method implies low mechanical stress, but it caused the alteration of cinnabar and white lead and the partial removal of this latter. Q-Switch (QS), Short Free Run (SFR) and Erbium-YAG lasers were not tested. Some case studies [43-45] show that the first (QS laser) causes the blackening of cinnabar and white lead. The second (SFR laser) acts mainly by spallation, leading to an increase in temperature and pressure, with the risk of causing excessive mechanical stress. The Erbium-YAG laser does not induce the alteration of the white lead and cinnabar, likely due to the presence of an organic binder, which protects the pigments [46]. However, in the present study, as the pictorial layers on the sculpture are very poor in binder, its use probably would have failed. Although the possibility of cleaning by temporarily fixing the polychrome layers with cyclododecane in ligroin $[24,36,47,48]$ also was considered, this method was found unsuitable for achieving a satisfactory level of cleaning. After tests, to re-establish the adhesion of the ochre films, which contain clay minerals, an attempt was made through moisturising (to eliminate electrostatic forces), a slight heating and pressure exerted with a thermocautery, and interposing Meline $x^{\circledR}$ [12]. This process was assumed to avoid the contraindications of a pre-consolidation and the introduction of substances which are extraneous to the artwork, but it was unsuccessful in our case study. To be shown in Section 5. Conclusion, the optimal way to clean and consolidate the pictorial films consisted of introducing the selected product, waiting for it to start to polymerise and cleaning, exploiting the "softening" action released by the water of the applied emulsion. A water cleaning gel (gellan gum [49,50]) was selected for the stone surfaces, characterised by the presence of little and scattered pictorial fragments: in this case, the punctual consolidation was performed before the surface cleaning.

To select the most suitable one, some inorganic and organic (synthetic and natural) products were selected based on their viscosity and particle size, two characteristics that allow the resin to penetrate through and among the layers. To know these data, we referred to the technical data sheets of the manufacturers which, however, are often incomplete. The products whose at least one of these two parameters is indicated in the data sheets were selected and those having a viscosity $\leq 1000 \mathrm{mPa} \cdot \mathrm{s}$ and a particle diameter $\leq 0.1 \mu \mathrm{m}$ were tested. Polyvinyl acetate-based polymers were not taken into account because they may hydrolyse releasing acetic acid, which is harmful to the lithotype. In pictorial films, hydrolysis of the ester is favoured by temperature and humidity and could be eventually catalysed by metal cations or oxides coming from pigments [37]. Synthetic products traditionally used on polychrome stone sculptures, such as Paraloid ${ }^{\circledR}$, were not tested, as they do not meet the viscosity and particle size requirements. An exception was made for the rabbit skin glue and the sturgeon glue, which are natural products commonly used in restoration, particularly in the field of paintings on wood, and for Funori, which was studied and applied for the adhesion of polychromy on stone also [24,51]. These resins have the advantage of being easily removable over time without using organic solvents, and of having a low toxicity. 
Following the tests, it was decided to use the acrylic microemulsion Dispersion ${ }^{\circledR} \mathrm{K} 52$ for the consolidation of the pictorial layers that cover the stone surfaces of the Virgin and the Child, thanks to its excellent adhesive strength, the absence of significant chromatic variations and its comparability with other products in terms of permeability.

Jun Funori provided excellent results and has a better stability to UV radiation than the acrylic resins $[24,25,27,42]$. Nevertheless, the cleaning tests performed on the Virgin with the Child revealed the suitability of the aqueous methods, which are incompatible with Funori. Regarding the average photosensitivity of the acrylic resins [39,52], we must consider that the selected microemulsion has a good penetration capacity, thus reducing this shortcoming; also, the risk of the presence of residues on the statue surfaces was reduced by cleaning with cotton swabs during the application phase. We finally must consider that the sculpture is conserved in a museum environment. It, therefore, is possible and necessary to monitor not only the thermohygrometric parameters, but also the exposure to light, avoiding irradiation with UV rays. These conditions also are essential to prevent the alteration of some constituent materials of the work of art itself, such as cinnabar, which are sensitive to light.

It seems clear that the adhesion of pictorial layers on a stone substrate causes a reduction in permeability. The water can leave a deposit of salts under the treated surface, which can rehydrate and recrystallize at any thermo-hygrometric variation. These phenomena lead to mechanical stresses within the porosity, causing breakages at the interfaces and the decohesion of materials [53]. The moisture that accumulates below the impermeable surface also can react with the constituent materials of the polychrome sculpture, such as the silver foil and the lithotype, thus participating in the formation of carboxylates [12]. Over the centuries, in addition to the siccative oil and the probable lean tempera, silver and golden foils were applied to decorate the work of art. Consequently, it is certainly necessary to deepen this research, to formulate more suitable products. Future research must focus not only on the compatibility, stability over time, retractability, good adhesive strength, and absence of chromatic alteration, but also on the permeability variation, caused by the introduction of an adhesive/consolidating agent in a complex and heterogeneous system.

\section{Conclusions}

The application of Dispersion ${ }^{\circledR} \mathrm{K} 52$ on the pictorial films of the sculpture confirmed the good results that emerged from the tests. The resin was applied by syringe at 8 and $16 \%$ in demineralised water over the pictorial layers which were in a state of decohesion and loss of adhesion, after the application of water and ethanol at $50 \%$. This allowed us to lower the surface tension and to partially wash away the deposits which were accumulated under the pictorial layers. Regarding more localised applications, the same product was used at 10\% in isopropyl alcohol [35], avoiding the use of water and ethanol at 50\% and the consequent dispersion. The introduction of the microemulsion hydrated the coherent deposits, allowing us to easily remove them with swabs or scalpels, reaching a satisfying cleaning level, without affecting the polychromy, thanks to the initial crosslinking of the resin. The microemulsion also softened the pictorial layers, allowing us to lay down the pictorial scales on the stone substrate, exerting a slight and gradual pressure with a spatula and swabs, and interposing Melinex ${ }^{\circledR}$. After that, the pictorial layers were more legible (Figure 4). 


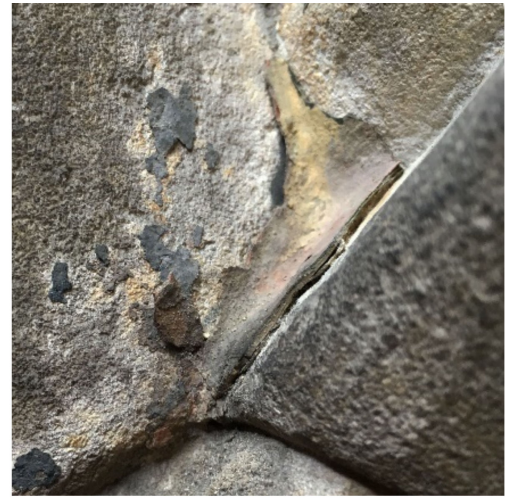

(a)

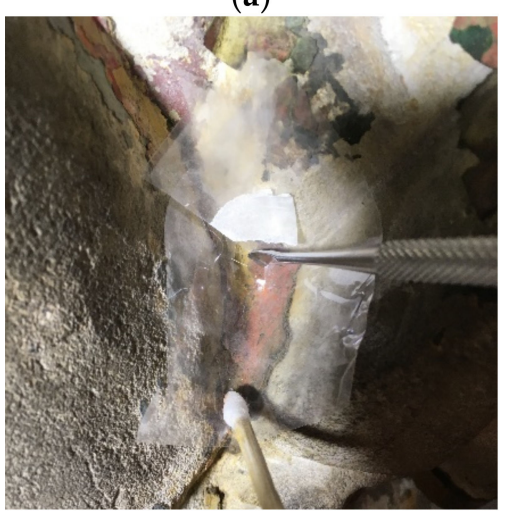

(c)

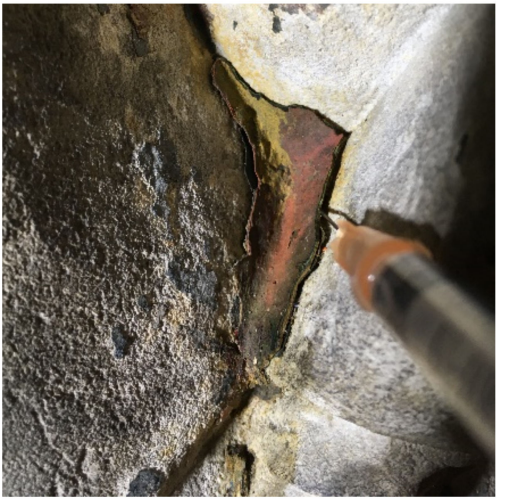

(b)

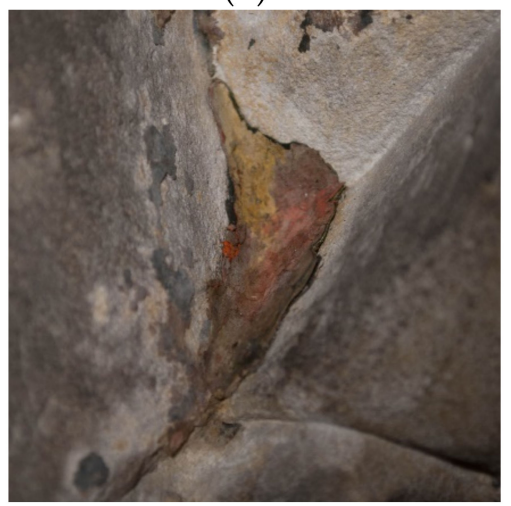

(d)

Figure 4. (a) The pictorial layers before the consolidation by syringe (b), cleaning with buffers and exerting a gradual pressure to adhere the films to the substrate (c). (d) After the consolidation.

Author Contributions: Conceptualisation, D.C., S.D.M., A.N. and M.N.; methodology, D.C., S.D.M., A.N., M.N.; validation, S.D.M., A.N. and M.N.; formal analysis, M.N.; resources, Centro Conservazione e Restauro "La Venaria Reale" in collaboration with Università degli Studi di Torino; data curation, A.N., M.N.; writing—original draft preparation, A.N; writing—review and editing, A.N., M.N.; visualisation, D.C., S.D.M., A.N. and M.N.; supervision, M.N. All authors have read and agreed to the published version of the manuscript.

Funding: This research received no external funding.

Institutional Review Board Statement: Not applicable.

Informed Consent Statement: Not applicable.

Data Availability Statement: Data is contained within the article.

Acknowledgments: We would like to thank Soprintendenza delle Belle Arti e Paesaggio per il Comune e la provincia di Torino, especially the art conservator Valeria Moratti and the conservator of Museo Civico d'Arte Antica di Torino Simone Baiocco for their kind permission.

Conflicts of Interest: The authors declare no conflict of interest. 


\section{Appendix A}

Table A1. The specimens subjected to tape test.

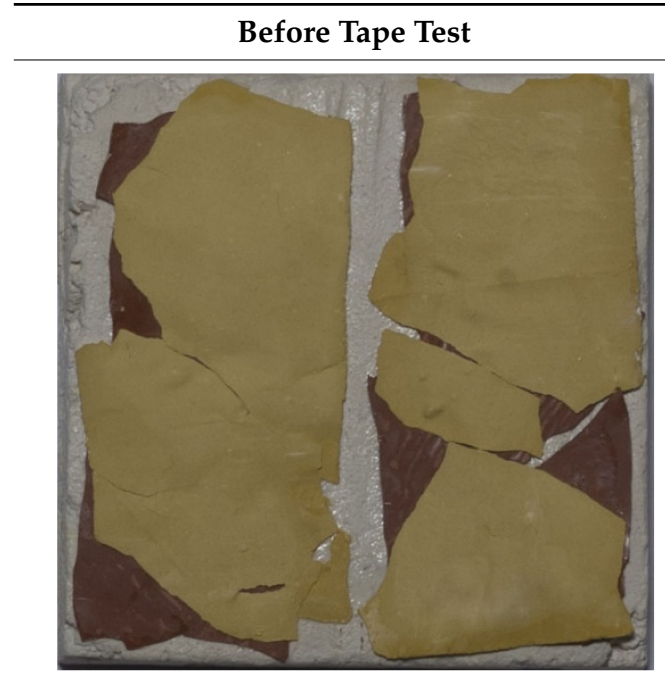

$25 \%$ and $50 \%$ Acril $^{\circledR} \mathrm{ME}$

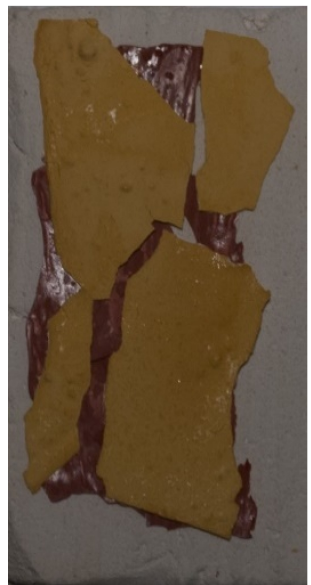

AcrilMat $^{\circledR}$

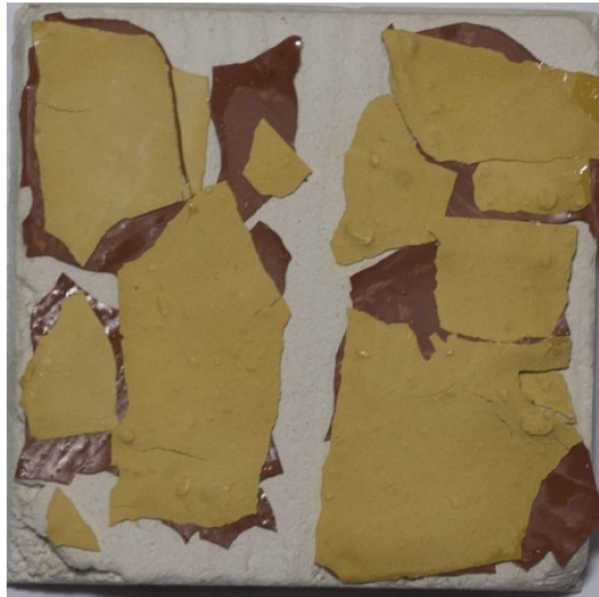

$3 \%$ and $10 \%$ Aquazol $^{\circledR} 200$
After Tape Test

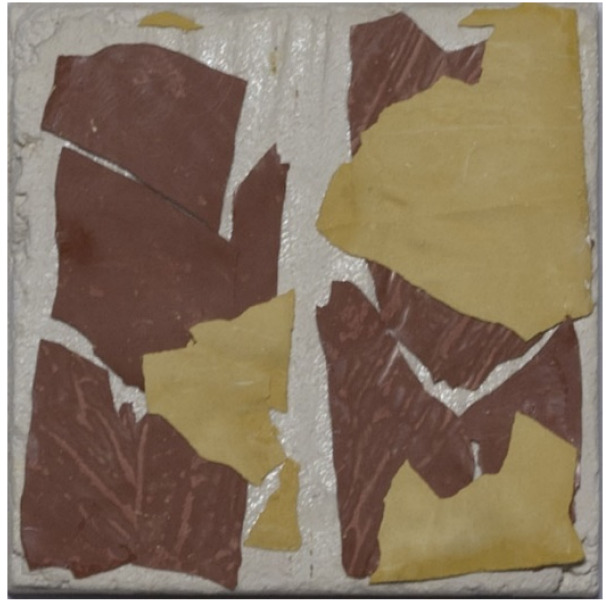

$25 \%$ and $50 \%$ Acril $^{\circledR} \mathrm{ME}$

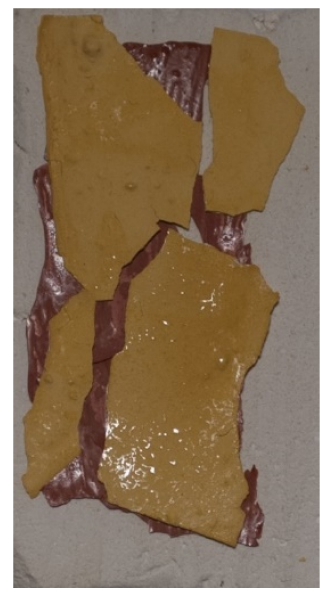

AcrilMat $^{\circledR}$

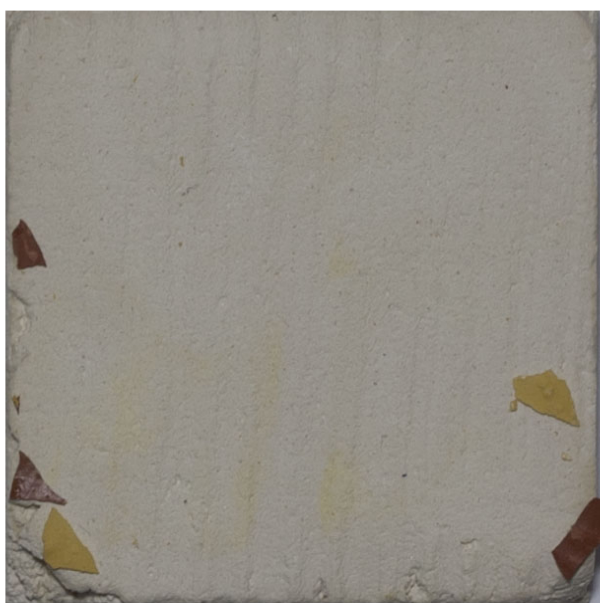

$3 \%$ and $10 \%$ Aquazol ${ }^{\circledR} 200$ 
Table A1. Cont.

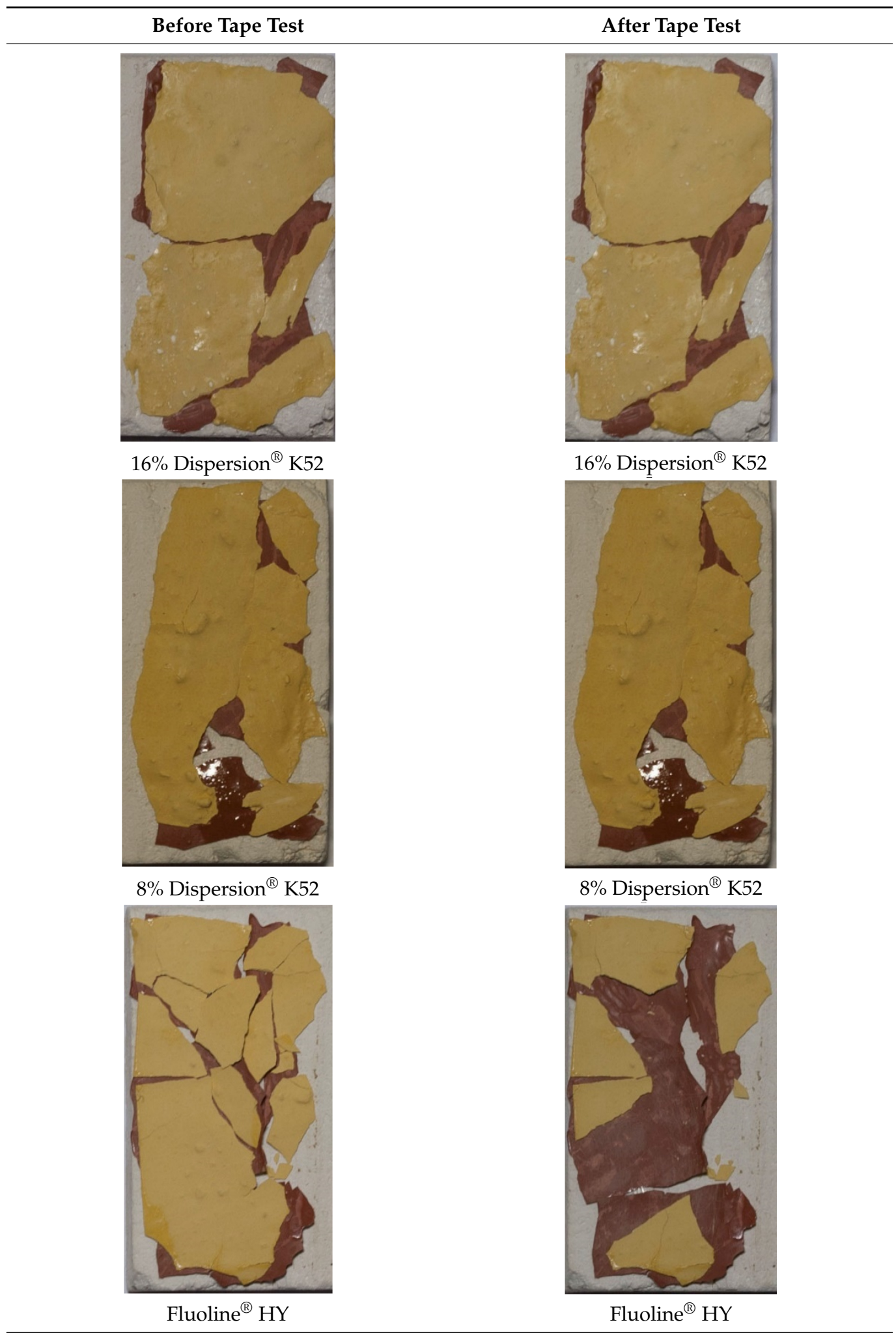


Table A1. Cont.

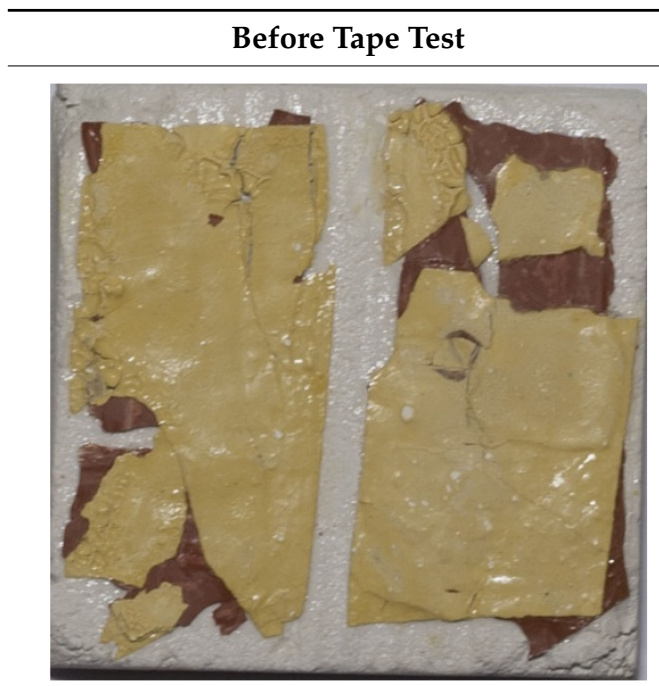

$33 \%$ and 50\% Micral-Primal ${ }^{\circledR}$ WS-24

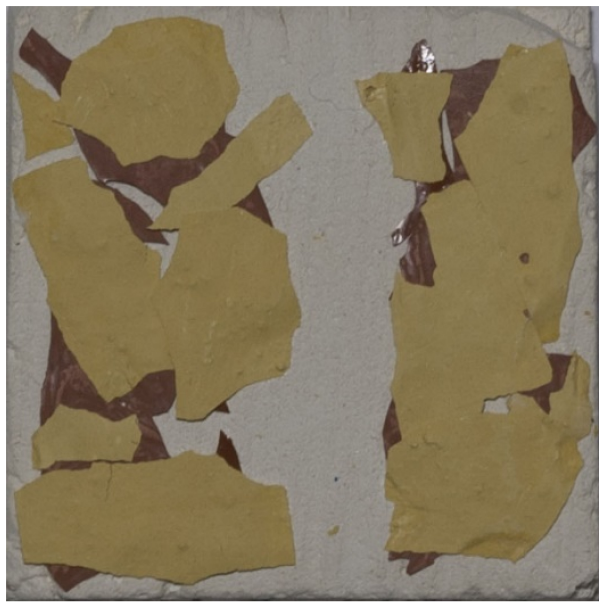

$1 \%$ and $3 \%$ Jun Funori

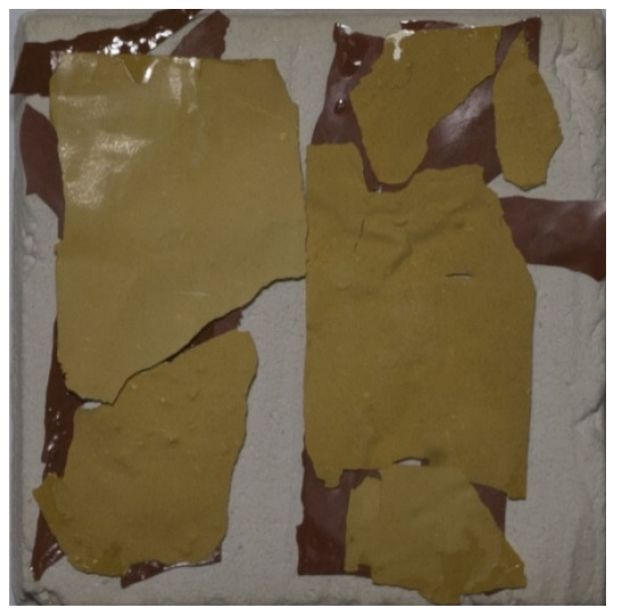

$10 \%$ and $20 \%$ Regalrez $^{\circledR} 1126$
After Tape Test

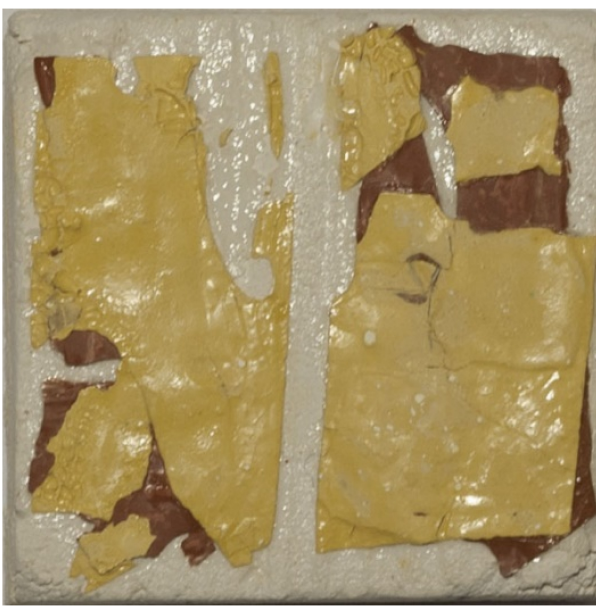

$33 \%$ and 50\% Micral-Primal ${ }^{\circledR}$ WS-24

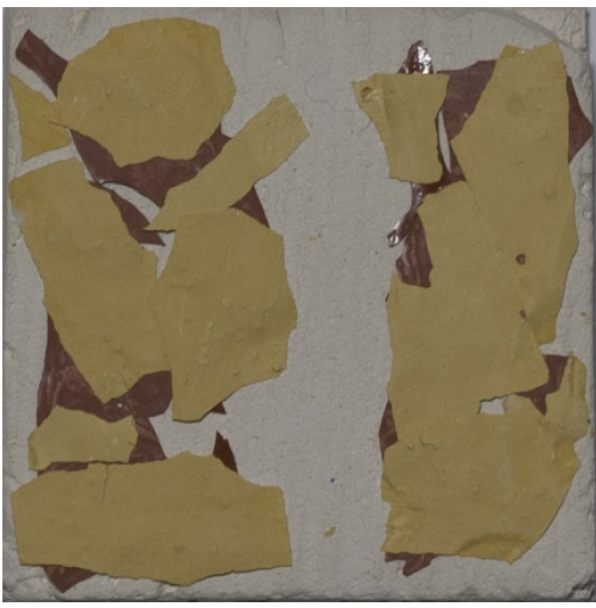

$1 \%$ and $3 \%$ Jun Funori

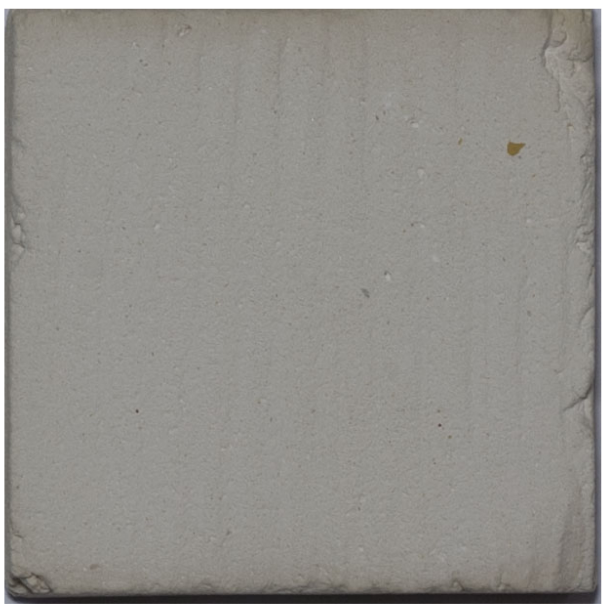

$10 \%$ and $20 \%$ Regalrez ${ }^{\circledR} 1126$ 
Table A1. Cont.

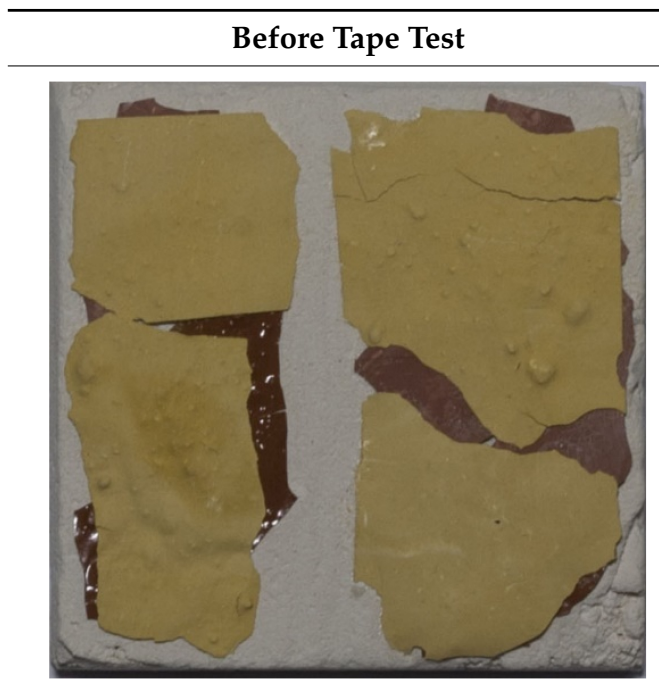

$5 \%$ and $10 \%$ Microacril ${ }^{\circledR}$ CV40

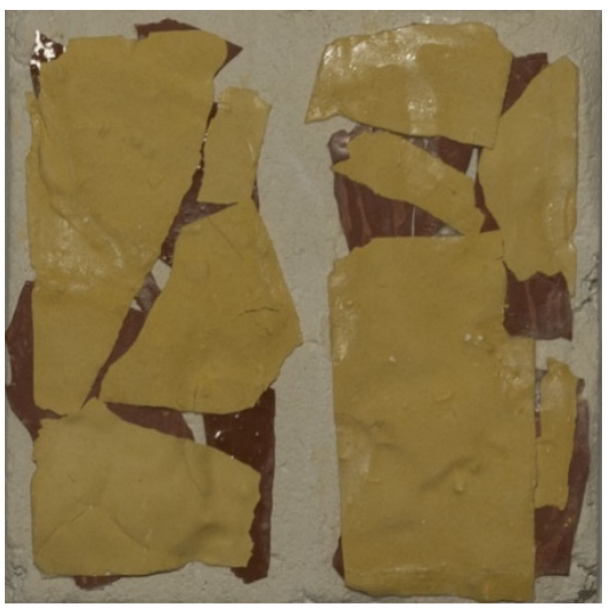

$2 \%$ and $4 \%$ Tylose ${ }^{\circledR}$ MH 300p

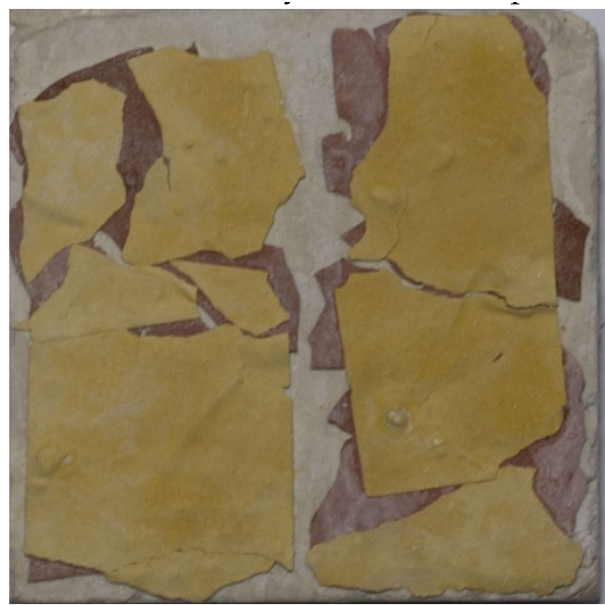

$2 \%$ and $5 \%$ ammonium oxalate
After Tape Test

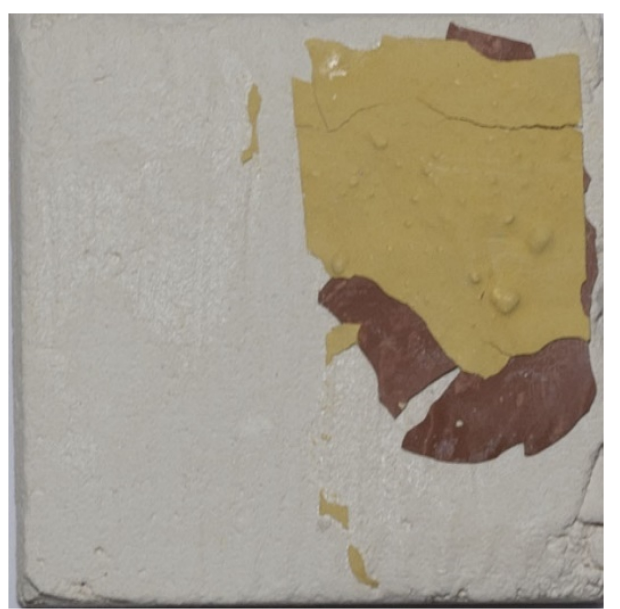

$5 \%$ and $10 \%$ Microacril ${ }^{\circledR}$ CV40

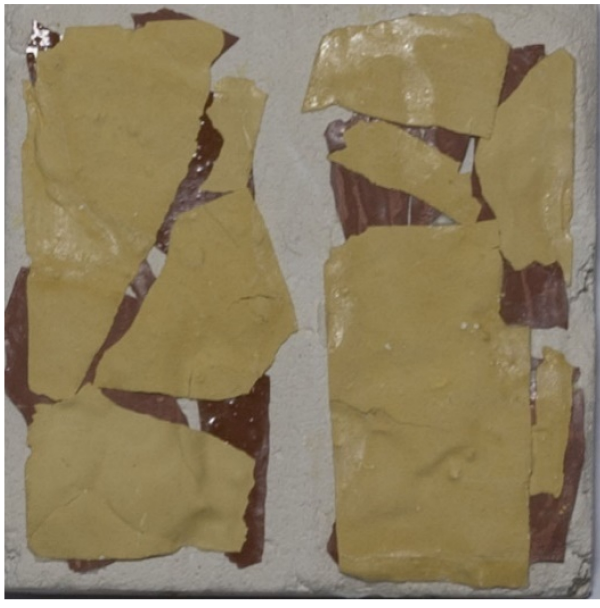

$2 \%$ and $4 \%$ Tylose ${ }^{\circledR}$ MH 300p

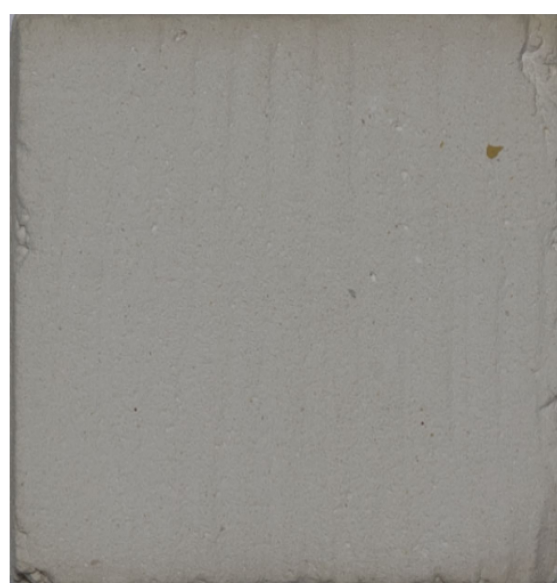

$2 \%$ and $5 \%$ ammonium oxalate 
Table A1. Cont.

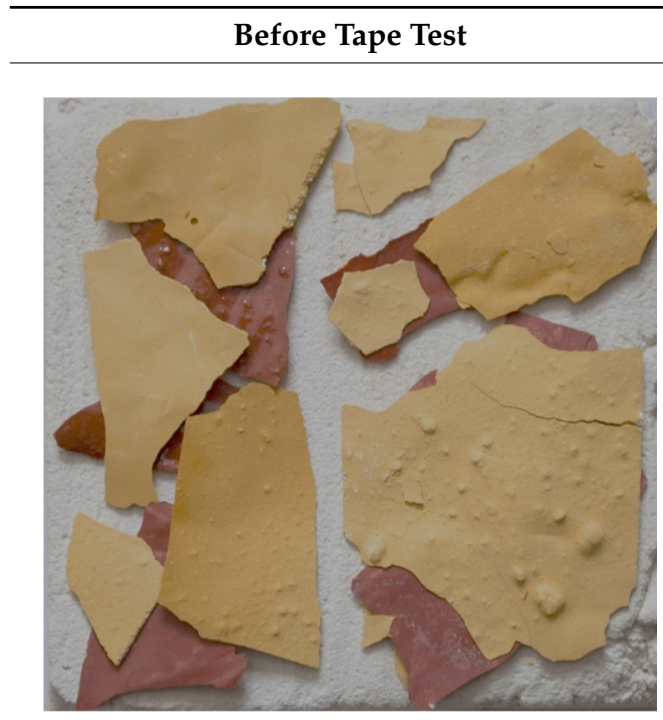

$\mathrm{CaLoSil}^{\circledR}$

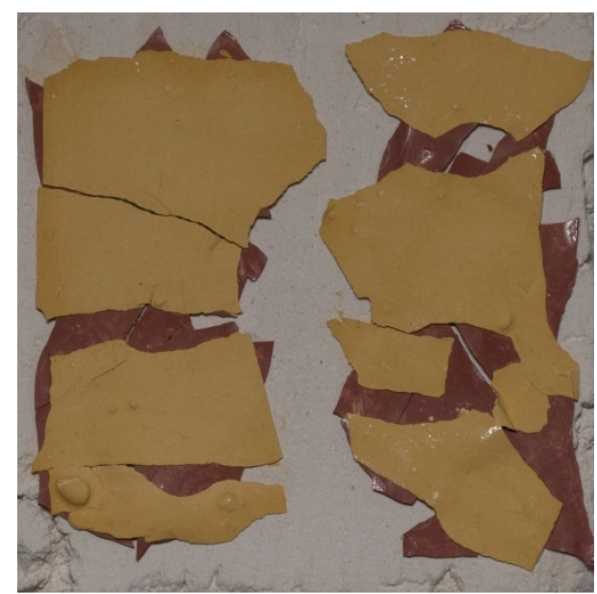

Rabbit glue Lapin and sturgeon glue
After Tape Test

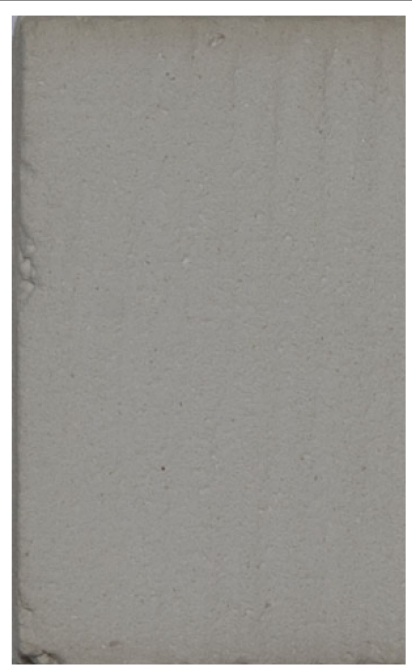

$\mathrm{CaLoSil}^{\circledR}$

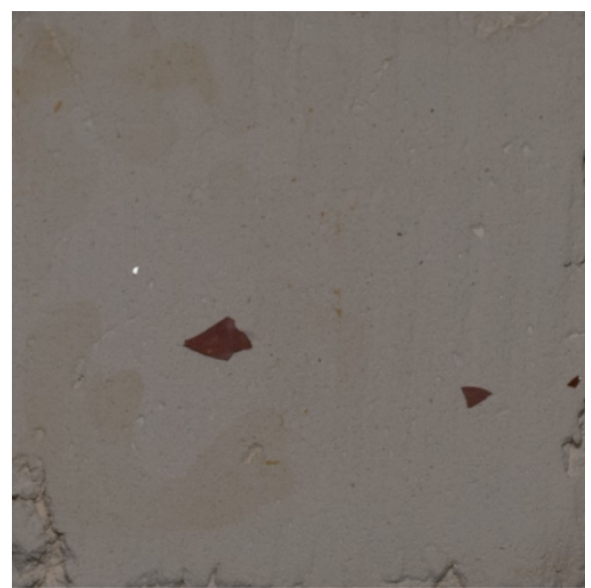

Rabbit glue Lapin and sturgeon glue

\section{References}

1. Mallé, L. Recenti acquisti di sculture antiche al Museo Civico di Torino. Cronache Econ. 1969, 322, 3.

2. Mallé, L. I Musei Civici di Torino. Acquisti e Doni 1966-1970. Catalogo Museo Civico di Torino; Galleria Civica d'Arte Moderna: Torino, Italy, 1970; p. 5.

3. Mallé, L. Palazzo Madama in Torino, II. Le Collezioni d'Arte; Tipografia Torinese Editrice: Torino, Italy, 1970.

4. Negri, A. Vergine Col Bambino Proveniente da Palazzo Madama: Studio E Intervento per la Conservazione Della Policromia E Il Recupero della Leggibilità Dell'Opera. Master's Thesis, Università Degli Studi di Torino, Turin, Italy, 2019.

5. Baron, F. Sculpture Francaise. I. Moyen Age; Rèunion des Musées Nationaux: Paris, France, 1996.

6. Baron, F.; Avril, F.; Chapu, P.; Gaborit-Chopin, D.; Perrot, F. Les Fastes du Gothique: Le Siècle de Charles V; Rèunion des Musées Nationaux: Paris, France, 1981.

7. Taburet-Delahaye, E.; Avril, F. Paris 1400: Les arts sous Charles VI, Paris. In Proceedings of the Musee du Louvre, Editions de la Réunion des Musées Nationaux, Paris, France, 22 March-12 July 2004; pp. 216-335.

8. Vv.Aa. Paris, 1400: Les arts sous Charles VI. Musée du Louvre. In Proceedings of the Fayard, Réunion des Musées Nationaux, Paris, France, 22 March-12 July 2004; pp. 216-335.

9. Mills, J.S.; White, R. The Organic Chemistry of Museum Objects; Butterworths: London, UK, 1994.

10. Matteini, M.; Moles, A. La Chimica nel Restauro. I Materiali dell'Arte Pittorica; Nardini Editore: Firenze, Italy, 2010.

11. Pizzini, S. Indagine Sul Comportamento Ossidativo di Film Pittorici ad Olio di Produzione Industriale Mediante Ozonizzazione e Caratterizzazione GC/MS. Master's Thesis, Università Ca' Foscari, Venice, Italy, 2012.

12. Aguado-Guardiola, E. Estudio Del Rol de Los Agregados Minerales en la Formación, Envejecimiento y Conservación de Películas Pictóricas Al Óleo. Ph.D. Thesis, Universitat Politècnica de València, Valencia, Spain, 2017. 
13. Mecklenburg, M.F.; Tumosa, C.S.; Erhardt, D. Structural response of painted wood surfaces to changes in ambient relative humidity. In Proceedings of the Painted Wood: History and Conservation, a symposium organized by the Wooden Artifacts Group of the American Institute for Conservation of Historic and Artistic Works and the Foundation of the AIC, Williamsburg, VA, USA, 11-14 November 1994; pp. 464-483.

14. Aguado-Guardiola, E.; Fuster-Lòpez, L. The role of stone substrate in oil paint film stability: An insight into some issues influencing durability and conservation. In Proceedings of the of Polychrome Sculpture: Decorative Practice and Artistic Tradition, ICOM-CC Interim Meeting, Working Group Sculpture, Polychromy, and Architectural Decoration, Tomar, Portugal, 28-29 May 2013; pp. 16-26.

15. Boon, J.J.; Keune, K.; Zucker, J. Imaging analytical studies of lead soaps aggregating in preprimed canvas used by the Hudson River School painter F.E. Church. Microsc. Microanal. 2005, 11, 444-445. [CrossRef]

16. Keune, K.; Boon, J.J. Analytical imaging studies of cross-sections of paintings affected by lead soap aggregate formation. Stud. Conserv. 2007, 52, 161-176. [CrossRef]

17. Boon, J.J.; Keune, K.; Van der Weerd, J.; Noble, P.; Wadum, J. Mechanical and chemical changes in Old Master paintings: Dissolution, metal soap formation and remineralization processes in lead pigmented ground/intermediate paint layers of 17th Century paintings. In Proceedings of the 13th Triennial Meeting of the ICOM Committee for Conservation, Rio de Janerio, Brazil, 22-27 September 2002.

18. Torraca, G. Lectures on Materials Science for Architectural Conservation; The Getty Conservation Institute: Los Angeles, CA, USA, 2009.

19. Rinaldi, S.; Quartullo, G.; Milaneschi, A.; Pietropaoli, R.; Occorsio, S.; Costantini Scala, F.; Minunno, G.; Virno, C. La Fabbrica dei Colori: Pigmenti e Coloranti Nella Pittura e Nella Tintoria; Il bagatto: Roma, Italy, 1995.

20. Bevilacqua, N.; Borgioli, L.; Adrover Garcia, I.; Matteini, M. I Pigmenti Nell'Arte: Dalla Preistoria Alla Rivoluzione Industriale; Il Prato: Vicenza, Italy, 2010.

21. Roy, A. Artists' Pigments: A Handbook of Their History and Characteristics; National Gallery of Art: Washington, DC, USA, 1993.

22. Lyon-Marion, B.A.; Mittelman, A.M.; Rayner, J.; Lantagne, D.S.; Pennell, K.D. Impact of chlorination on silver elution from ceramic water filters. Water Res. 2018, 142, 471-479. [CrossRef] [PubMed]

23. Borgioli, L.; Camaiti, M.; Rosi, L. Comportamento all'irraggiamento UV di nuovi formulati polimerici per il restauro. In Proceedings of the VI Congresso Annuale IGIIC, Spoleto, Italy, 2-4 October 2008.

24. Prestipino, G.; Santamaria, U.; Morresi, F.; Amenta, A.; Greco, C. Sperimentazione di adesivi e consolidanti per il restauro di manufatti lignei policromi egizi. In Proceedings of the Lo Stato dell'Arte, XIII Congresso Nazionale IGIIC, Centro Conservazione e Restauro La Venaria Reale, Torino, Italy, 22-24 October 2015.

25. Kunzelman, D. L'attenzione alle superfici pittoriche. Materiali e metodi per il consolidamento e metodi scientifici per valutarne l'efficacia. In Proceedings of the the IV Congresso Internazionale Colore e Conservazione, Materiali e Metodi nel Restauro Delle Opere Policrome Mobili, Milano, Italy, 21-22 November 2008.

26. Geiger, T.; Michel, F. Studies on the polysaccharide JunFunori used to consolidate matt paint. Stud. Conserv. 2005, 50, 193-204. [CrossRef]

27. Finozzi, A. Progetto Restauro. Speciale n. 62. Utilizzo Della Colla Funori Nel Restauro; Il Prato: Saonara, Italy, 2006.

28. Llamas Pacheco, R.; San Pedro, D.R. Colorimetric evaluation of three adhesives used in the consolidation of contemporary matte paint after artificial ageing. Conserv. Patrimònio 2014, 20, 11-21. [CrossRef]

29. Harrold, J.; Wyszomirska-Noga, Z. Funori: The use of a traditional Japanese adhesive in the preservation and conservation treatment of Western objects. In Adapt \& Evolve 2015: East Asian Materials and Techniques in Western Conservation, Proceedings of the International Conference of the Icon Book E Paper Group, London, UK, 8-10 April 2015; The Institute of Conservation: London, UK, 2017; pp. 68-79.

30. Matteini, M. Inorganic treatments for the consolidation and protection of stone artefacts and mural paintings. CSCH 2008, 8 , 13-27. [CrossRef]

31. Borgioli, L. Protezione e Consolidamento con "Bario Idrato" ed "Ammonio Ossalato"; Technical Report; CTS: Hopkinton, MA, USA, 2012; pp. 1-7.

32. Di Gaetano, S. Restauro di Due Sculture Lapidee con Tracce di Policromia: Studio di Ricomposizione Non Invasivo. Master's Thesis, Università Degli Studi di Torino, Turin, Italy, 2015.

33. Genova, I. Il Restauro del Bozzetto Scultoreo del Carro di San Rocco di Pietro Consagra. Uno Studio Sul Comportamento Chimico-Fisico di Leganti Pittorici Impiegati Nell'Arte Contemporanea. Master's Thesis, Università Degli Studi di Palermo, Palermo, Italy, 2015.

34. Puglisi, C.; Reginella, M.L.; Sottile, S.; Bruno, M.; Vitella, M. Restoration of a polymateric sculpture of the immaculate conception. Eur. J. Sci. Theol. 2017, 13, 69-77.

35. Rubino, C. Definizione Delle Metodologie di Intervento Su Un Dipinto Murale di Età Romana Proveniente Dall' Area Vesuviana: Sistemi Tradizionali ed Innovativi a Confronto Per Il Recupero Della Superficie Pittorica. Master's Thesis, Università Degli Studi di Torino, Turin, Italy, 2018.

36. Pelottieri, M. Il Restauro di Una Scultura in Marmo Dipinta del Museo Civico D'Arte Antica di Torino: Studio e Progettazione di Un Metodo di Pulitura e Consolidamento. Master's Thesis, Università Degli Studi di Torino, Turin, Italy, 2018.

37. Borgioli, L.; Cremonesi, P. Le Resine Sintetiche Usate nel Trattamento di Opere Policrome; Il Prato: Saonara, Italy, 2005. 
38. Wolbers, R.C.; McGynn, M.; Duerbeck, D. Poly(2-Ethyl-2-Oxazoline): A new conservation consolidant. In Painted Wood: History and Conservation, Proceedings of the Symposium in Williamsburg, November 11-14, 1994; Getty Conservation Institute: Los Angeles, CA, USA, 1994; pp. 514-527.

39. Semenzato, C. Studio e Analisi del Degrado di Leganti Polimerici Utilizzati per il Ritocco Pittorico. Master's Thesis, Università Ca' Foscari Venezia, Venice, Italy, 2015.

40. Arslanoglu, J. Evaluation of the use of Aquazol as an adhesive in painting conservation. WAAC Newsl. 2003, 25, 2.

41. Borgioli, L. Polimeri di Sintesi per la Conservazione della Pietra; Il Prato: Saonara, Italy, 2006.

42. Castelli, G.; Gigli, M.C.; Lalli, C.; Lanterna, G.; Weiss, C.; Speranza, L. Un composto organico sintetico per il consolidamento del legno: Sperimentazione, misure e prime applicazioni. OPD Restauro 2002, 14, 144-152.

43. Pouli, P.; Emmony, D.C.; Madden, C.E.; Sutherland, I. Analysis of the laser-induced reduction mechanisms of medieval pigments. Appl. Surf. Sci. 2001, 173, 252-261. [CrossRef]

44. Cooper, M.I.; Fowles, P.S.; Tang, C.C. Analysis of the laser-induced discoloration of lead white pigment. Appl. Surf. Sci. 2002, 201, 75-84. [CrossRef]

45. Pustka, M.L.; Violini, P.; Cencia, F.; Ferlito, A.; Giacomazzi, P.; Heiniger, C.; Leopardi, F.; Munzi, C.; Pinto, G.; Sechi, S.; et al. La rimozione di ridipinture a biacca alterate sugli affreschi della cappella di San Lorenzo alla Scala Santa. In Proceedings of the Aplar 5. Applicazioni Laser Nel Restauro, Musei Vaticani, Vatican, 18-20 September 2014.

46. Korenberg, C.; Pereira-Pardo, L. The use of erbium lasers for the conservation of cultural heritage. A review. J. Cult. Herit. 2018, 31, 236-247. [CrossRef]

47. Anselmi, C.; Presciutti, F.; Doherty, B.; Daveri, A.; Miliani, C.; Brunetti, B.G.; Sgamellotti, A. Ottimizzazione dei metodi di applicazione del ciclododecano come protettivo temporaneo per interventi in emergenza. In Proceedings of the Lo Stato dell'Arte, VI Congresso Nazionale IGIIC, Spoleto, Italy, 2-4 October 2008.

48. Rowe, S.; Rozeik, C. The uses of cyclododecane in conservation. Stud. Conserv. 2008, 53, 17-31. [CrossRef]

49. Cremonesi, P. L'ambiente Acquoso per il Trattamento di Opere Policrome; Il Prato: Saonara, Italy, 2012.

50. Placido, M. Il Restauro e la Protezione della Carta Mediante Trattamento con Gel di Gellano. Master's Thesis, Università Sapienza, Rome, Italy, 2019.

51. Gérard-Bendelé, A.; Le Pogam, P.Y. Un retable du XIV siècle (musée de Bar-le-Duc): La complémentarité de la sculpture et de la polychromie. Techné 2014, 39, 87-89.

52. Clifton, J.R. Stone Consolidating Materials: A Status Report; U.S. Department of Commerce, National Bureau of Standards: Washington, DC, USA, 1980.

53. Casoli, A.; Cauzzi, D.; Palla, G. Lo studio dei leganti in opere policrome: Gli oli siccativi. OPD Restauro 1999, 11, $115-117$. 